\title{
Characterization of the milk lipid fraction in non-dairy sheep breeds
}

\author{
A. J. Rozbicka-Wieczorek ${ }^{1}$, A. Radzik-Rant ${ }^{2}$, W. Rant ${ }^{2}$, B. Kuczyńska ${ }^{2}$, and M. Czauderna ${ }^{1}$ \\ ${ }^{1}$ The Kielanowski Institute of Animal Physiology and Nutrition, Polish Academy of Sciences, \\ 05-110 Jabłonna, Poland \\ ${ }^{2}$ Department of Animal Breeding, Warsaw University of Life Sciences - SGGW, Ciszewskiego 8, \\ 02-786 Warsaw, Poland
}

Correspondence to: A. J. Rozbicka-Wieczorek (a.wieczorek@ifzz.pl)

Received: 24 April 2015 - Revised: 2 October 2015 - Accepted: 21 October 2015 - Published: 5 November 2015

\begin{abstract}
Studies regarding the composition of milk fat are mostly conducted on dairy breeds. The aim of our studies was to evaluate the fatty acid, cholesterol and phospholipid amount in the milk of two non-dairy sheep breeds. The study was conducted on 60 ewes (Żelaźnieńska strain of Polish Lowland sheep - 30 ewes; Wrzosówka breed - 30 ewes) from one flock which were kept under the same conditions and maintenance. There were no differences in the amount of the basic components of milk in these two breeds. In the lipid fraction of Wrzosówka sheep (a more primitive breed), higher amounts of eicosapentaenoic acid (EPA) and docosahexaenoic acid (DHA) $(P \leq 0.05)$, a higher amount of polyunsaturated fatty acids (PUFAs) $n-3(P \leq$ $0.01)$ and a lower ratio of n-6/n-3 $(P \leq 0.01)$ were recorded compared to Żelaźnieńska sheep. The milk of Żelaźnieńska sheep had a higher amount of cholesterol $(P \leq 0.05)$. There were no differences in concentrations of phospholipids.

With regard to the two non-dairy sheep breeds, a higher amount of PUFAs n-3 and a more favorable ratio of n- $6 /$ n-3 was observed in the milk of the more primitive breed (i.e., Wrzosówka sheep).
\end{abstract}

\section{Introduction}

For several millions of people around the world, milk is an essential dietary component. It contains numerous nutrients, and many of these possess health-promoting properties. However, milk and dairy products are an important source of saturated fatty acids (SFAs), which, in the past, were perceived as a risk factor for human health, especially cardiovascular disease (CVD) and stroke. Over the past 2 decades, scientists have examined the influence of diets rich in dairy products and the risk of the development of CVD. Most of the studies have shown no relationship between the consumption of milk fat and the risk of CVD (Huth and Park, 2012). This might be due to the fact that milk fat contains many functional components besides SFAs, including unsaturated fatty acids (UFAs) such linoleic acid (LA), $\alpha$ linolenic acid ( $\alpha$ LNA), arachidonic acid (AA), eicosapentaenoic acid (EPA), docosahexaenoic acid (DHA), conjugated linoleic acid (CLA) isomers, phospholipids and some sterols including cholesterol (Park et al., 2007). Polyunsaturated fatty acids like LA (PUFAs n-6) and $\alpha$ LNA (PUFAs n-3) are recognized as essential fatty acids in the human diet. Because they cannot be synthesized by the human metabolism, they must be supplied in the diet. There are numerous investigations concerning the influence of polyunsaturated fatty acids on human health. In contrast to PUFAs n-6, PUFAs n-3 possess health-promoting properties, such as preventing cardiovascular disease and reducing the risk of cancer. They also have an important role in the prevention and treatment of diabetes, arthritis and inflammatory and autoimmune disorders. Long-chain PUFAs like EPA and DHA are also important in the diet of infants, where they are responsible for the proper development of the nervous system and the retina (Parodi, 2004).

The milk and meat of ruminants, especially sheep, are rich in CLA. The cis-9, trans-11 isomer makes up 70-95\% of all CLA and has strong biological properties. One of the 
Table 1. The chemical composition of feeds used in nutrition of examined ewes.

\begin{tabular}{lrrr}
\hline Specification & Cereal meal & Grass hay & Oat straw \\
\hline Dry matter $\left(\mathrm{g} \mathrm{kg}^{-1}\right)$ & 892.4 & 908.2 & 911.0 \\
Crude protein $\left(\mathrm{g} \mathrm{kg}^{-1}\right)$ & 118.0 & 88.0 & 30.6 \\
Ether extract $\left(\mathrm{g} \mathrm{kg}^{-1}\right)$ & 17.2 & 13.6 & 12.4 \\
Crude fibre $\left(\mathrm{g} \mathrm{kg}^{-1}\right)$ & 48.9 & 345.5 & 412.4 \\
Ash $\left(\mathrm{g} \mathrm{kg}^{-1}\right)$ & 20.0 & 68.1 & 62.3 \\
$\mathrm{EN}(\mathrm{MJ} / 1 \mathrm{~kg} \mathrm{DM})$ & 7.54 & 4.27 & - \\
\hline
\end{tabular}

EN: net energy, MJ: megajoule, DM: dry matter.

most important features is its anticarcinogenic effect (Parodi, 2003; Collomb et al., 2006; Park et al., 2007; RozbickaWieczorek et al., 2013., Scollan et al., 2014). Moreover, cis9, trans-11 CLA can inhibit the development of cardiovascular disease and type 2 diabetes. It also has bacteriostatic and immunoregulatory properties (Collomb et al., 2006)

Phospholipids are associated with the milk fat globule membrane and account for $0.2-1 \%$ of all milk lipids. Phospholipids and sphingomyelin as well as their metabolites are reported to have tumor-suppressing properties by influencing cell proliferation and are highly bioactive compounds with bacteriostatic and cholesterol-lowering properties (Parodi, 2004).

The source of the biologically active components of the milk lipid fraction may be products obtained from the processing of sheep milk. In non-dairy sheep breeds it can be found in lamb meat. Milk as the basic feed of suckling lambs can affect the amount of functional components in intramuscular fat (Scerra et al., 2007; Radzik-Rant et al., 2012).

Most of the research on the composition of milk fat was conducted on dairy sheep breeds and focused on the influence of diet on the level of UFAs, and especially CLA isomers, in sheep milk. Investigations regarding non-dairy sheep breeds are rather limited. The objective of this work was to study the amount of specific components of the milk lipid fraction of two breeds, which are non-dairy and were kept under the same management and, particularly, feeding practices.

\section{Material and methods}

\subsection{Animals, treatment and sampling}

The study was carried out on two non-dairy sheep breeds: Wrzosówka sheep (30 ewes), which belong to the group of primitive breeds, and the Żelaźnieńska strain of Polish Lowland sheep (30 ewes), a meat and wool breed; both groups were kept on the experimental farm of the Warsaw University of Life Sciences, under the same conditions and maintenance. Milk samples were collected from ewes aged 34 years, which were at peak lactation (fourth week). The
Table 2. The fatty acid profile of feeds used in nutrition of examined ewes.

\begin{tabular}{lrr}
\hline Fatty acids $\left(\mathrm{g} \mathrm{kg}^{-1}\right.$ fat $)$ & Cereal meal & Grass hay \\
\hline C12:0 & - & 4.2 \\
C14 : & 1.5 & 6.8 \\
C16:0 & 157.1 & 220.7 \\
C16 $: 1$ cis-9 & 1.6 & 2.3 \\
C18 $: 0$ & 13.7 & 33.1 \\
C18 $: 1$ cis-9 & 203.7 & 49.6 \\
C18: $($ LA $)$ & 524.9 & 148.5 \\
C18 $: 3$ n-3 $(\alpha$ LNA $)$ & 41.7 & 188.9 \\
\hline
\end{tabular}

sheep were fed according to specific standards (Osikowski et al., 1998). The diet of ewes of both breeds was based on local feeds: cereal meal (oat meal 30\%, barley meal $40 \%$, wheat meal $10 \%$, wheat bran $20 \%$ ), grass hay, oat straw and a mineral mixture. The chemical composition, nutritional value of fodder and the fatty acid profile are presented in Tables 1 and 2. Ewes were fed two times a day: in the morning and evening. Fresh water was available ad libitum. Milk samples were collected in the morning. The lambs were separated from their dams $2 \mathrm{~h}$ before milk collection; then ewes were hand milked. A representative milk sample $(100 \mathrm{~mL})$ was taken from the full udder of each ewe (a total of 60 milk samples) and placed in a sterile bottle with a preservative (Mlekostat CC). Immediately after collection, milk samples were transferred to the Milk Testing Laboratory of Warsaw University of Life Sciences in order to perform the analysis of their composition. In order to evaluate milk yield, lambs were weighed at birth and at 28 days of age. For $1 \mathrm{~kg}$ of body weight gain, a consumption of $4.5 \mathrm{~kg}$ of milk (Molik et al., 2008) was assumed. Milk yield was calculated for $1 \mathrm{~kg}$ of metabolic weight.

\subsubsection{Chemical analysis}

Basic parameters of the milk, i.e., fat, protein, casein, lactose and total solid (TS) amount, were determined by a Milkoscan FT-120 instrument (Foss Electric, Hillerod, Denmark). Milk fat was extracted according to the Röse-Gottlieb procedure (AOAC, 1990). Fatty acids of milk lipids were methylated according to the transestrification method EN ISO 5509. The separation and quantification of fatty acid methyl esters (FAMEs) were carried out by gas chromatography using an Agilent 7890A GC (Agilent) with a flame-ionization detector (HP Chem software) equipped with a Varian Select FAME capillary column (length $-100 \mathrm{~m}$; internal diameter $-0.25 \mathrm{~mm}$; film thickness - $0.25 \mu \mathrm{m}$; Varian/Agilent Technologies, Waldbronn, Germany). Operating conditions were as follows: helium flow $-25 \mathrm{~cm}$ per $1 \mathrm{~s}$; flame-ionization detector (FID) at $300^{\circ} \mathrm{C}$; split-splitless injector at $240^{\circ} \mathrm{C}$. The temperature program was as follows: $130^{\circ} \mathrm{C}$ for $1 \mathrm{~min}$; 130 $170^{\circ} \mathrm{C}$ at $6.5^{\circ} \mathrm{C} \mathrm{min}^{-1} ; 170-215^{\circ} \mathrm{C}$ at $2.75^{\circ} \mathrm{min}^{-1} ; 215^{\circ} \mathrm{C}$ 
Table 3. Milk yield and the amount of basic components in examined sheep breeds.

\begin{tabular}{lrrrc}
\hline & $\begin{array}{r}\text { Wrzosówka } \\
n=30\end{array}$ & $\begin{array}{r}\text { Lowland sheep } \\
n=30\end{array}$ & SE & $\begin{array}{c}\text { Statistical } \\
\text { significance }\end{array}$ \\
\cline { 2 - 3 } & LSM & LSM & & \\
\hline Milk yield $(\mathrm{kg})$ & 32.32 & 40.35 & 2.09 & $\mathrm{~ns}$ \\
Milk yield $\left(\mathrm{kg} \mathrm{kg}^{-1}\right)^{*}$ & 2.12 & 1.93 & 0.12 & $\mathrm{~ns}$ \\
Fat $\left(\mathrm{g} \mathrm{kg}^{-1}\right)$ & 89.1 & 82.1 & 2.5 & $\mathrm{~ns}$ \\
Protein $\left(\mathrm{g} \mathrm{kg}^{-1}\right)$ & 49.7 & 51.3 & 0.5 & $\mathrm{~ns}$ \\
Lactose $\left(\mathrm{g} \mathrm{kg}^{-1}\right)$ & 52.1 & 51.5 & 0.5 & $\mathrm{~ns}$ \\
Total solids $\left(\mathrm{g} \mathrm{kg}^{-1}\right)$ & 200.4 & 195.1 & 2.4 & $\mathrm{~ns}$ \\
\hline
\end{tabular}

* Metabolic body weight; ns: not significant $(P>0.5)$; SE: standard error of the mean; LSM: least square mean.

for $12 \mathrm{~min}, 215-230^{\circ} \mathrm{C}$ at $20^{\circ} \mathrm{C} \mathrm{min}-1$ and $230^{\circ} \mathrm{C}$ for $3 \mathrm{~min}$. Each peak was identified and quantified using pure methyl ester standards: PUFA no. 1, Lot LB 75066; PUFA no. 2, Lot LB 83491; FAME Mix RM-6, Lot LB 68242; Supelco 37 Comp. FAME Mix, Lot LB 68887 (Supelco, Bellefonte, PA, USA). Concentrations of fatty acids in analyzed milk fat have included in the fatty acids standard concentration ranges (Puppel, 2011; Puppel et al., 2015).

Cholesterol and phospholipids were determined by spectrophotometry of eluates at a wavelength range of 190$320 \mathrm{~nm}$, following Puppel (2011). The ether extract of milk fat was separated by using the thin-layer chromatography method on an activated silica gel. Chromatograms were developed with hexane, ethyl ether and formic acid in a ratio of $80: 20: 2$. The identification of the obtained compounds were performed using UV lamp excitation at $254 \mathrm{~nm}$, followed by fluorescence measurement of dichlorofluorescein, based on a Rf (retardation factor) of analyzed components and using a set of standards (Holme and Peck, 1994). Quantitative analysis was performed using the absorption method.

\subsubsection{Statistical analysis}

Statistical analyses of the data of the chemical composition of the milk fatty acid was performed using the SPSS 12.0 software (2003), based on a linear model that included the effect of breed. All effects were tested against residual middlesquares to determine the level of significance.

\section{Results and discussion}

Despite the differences in morphological traits, both studied breeds did not differ in milk performance potential, especially in their performance per $1 \mathrm{~kg}$ of metabolic weight for the first month of lactation (Table 3).

There were no differences in the amount of basic milk components like fat, protein, lactose and dry matter (Table 3). Comparing the milk composition of studied sheep with that of other breeds, the greatest differences were ob- served in fat content. The milk of Polish Merino and Polish mountain sheep in the fourth week of lactation contained lower amounts of fat $\left(78.2 \mathrm{~kg}^{-1}\right.$, Polish Merino) than in the Wrzosówka breed $\left(70.4 \mathrm{~kg}^{-1}\right.$, Polish mountain sheep, vs. $89.1 \mathrm{~kg}^{-1}$, Wrzosówka breed) and Żelaźnieńska strain of Polish Lowland sheep $\left(82.1 \mathrm{~kg}^{-1}\right.$, Radzik-Rant et al., 2011) studied here. A significantly higher amount of fat (reaching $126.0 \mathrm{~kg}^{-1}$ ) was reported by Wolth et al. (1981) in the Dorset breed, also a non-dairy sheep breed. However, less variation in the amount of basic components of sheep milk, including fat in dairy sheep breeds was observed in breeds from the Mediterranean region, such as Lacaune $\left(74.0 \mathrm{~kg}^{-1}\right)$, Manchega $\left(78.0 \mathrm{~kg}^{-1}\right)$ or Chios $\left(79.0 \mathrm{~kg}^{-1}\right)$ (Haenlein, 2001).

There were no significant differences in the amount of SFAs in the milk of examined breeds. The exception is the fatty acid with an odd number of carbon atoms (i.e., C15:0), of which there was more $(P \leq 0.01)$ in Wrzosówka milk fat (Table 4).

Regarding SFAs, the highest amount of milk fat in the sheep breeds examined was determined for palmitic acid (C16:0) and stearic acid (C18:0). The proportion of those acids in the group of SFAs was similar in the milk of examined breeds: C16:0 and C18:0 (for Wrzosówka breed: 43.4, 20.3\%, respectively; for Żelaźnieńska sheep: 42.3, $21.1 \%$, respectively; Tables 4 and 5). Comparing the results to other research that was also carried out on non-dairy sheep breeds, a slightly higher amount of stearic acid (C18:0) was obtained in Polish Merino milk (14.64 $\mathrm{g} \mathrm{kg}^{-1}$ fat) in the fourth week of lactation (Radzik-Rant et al., 2011). A similar amount of C16:0 and C18:0 was obtained by Talpur et al. (2009) in the milk fat of thin-tailed mutton Kooka and wool Kachi. Carta et al. (2002) noted lower amount of these

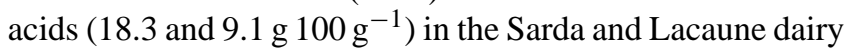
crossbreeds.

The greatest differences in the amount of SFAs between the resuls presented and other studies relate mainly to shortchain fatty acids (SCFAs) (C4-C10) (Table 4). Their amount in the milk of the Wrzosówka breed and Żelaźnieńska sheep 


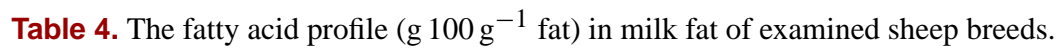

\begin{tabular}{|c|c|c|c|c|}
\hline \multirow[t]{2}{*}{ Fatty acids } & $\begin{array}{r}\text { Wrzosówka } \\
n=30\end{array}$ & $\begin{array}{r}\text { Lowland sheep } \\
n=30\end{array}$ & \multirow[t]{2}{*}{ SE } & \multirow[t]{2}{*}{$\begin{array}{l}\text { Statistical } \\
\text { significance }\end{array}$} \\
\hline & LSM & LSM & & \\
\hline $\mathrm{C} 4: 0$ & 1.59 & 1.75 & 0.39 & ns \\
\hline C6: 0 & 1.17 & 1.16 & 0.07 & $\mathrm{~ns}$ \\
\hline C8: 0 & 1.36 & 1.27 & 0.07 & ns \\
\hline $\mathrm{C} 10: 0$ & 4.27 & 4.83 & 0.24 & ns \\
\hline C12:0 & 2.65 & 2.57 & 0.16 & ns \\
\hline $\mathrm{C} 14: 0$ & 6.83 & 6.96 & 0.39 & ns \\
\hline C15:0 & 0.98 & 0.76 & 0.05 & $P \leq 0.01$ \\
\hline C16:0 & 24.09 & 23.93 & 0.9 & ns \\
\hline C17:0 & 1.41 & 1.41 & 0.06 & ns \\
\hline C18:0 & 11.28 & 11.96 & 0.55 & ns \\
\hline C10: 1 cis-9 & 0.11 & 0.08 & 0.01 & $P \leq 0.01$ \\
\hline C12: 1 cis -9 & 0.04 & 0.05 & 0.02 & ns \\
\hline C14: 1 cis-9 & 0.45 & 0.42 & 0.03 & ns \\
\hline $\mathrm{C} 15: 1$ & 0.26 & 0.26 & 0.01 & ns \\
\hline C16: 1 cis -9 & 0.7 & 0.64 & 0.04 & $\mathrm{~ns}$ \\
\hline $\mathrm{C} 16: 1$ iso $^{*}$ & 0.85 & 0.9 & 0.04 & ns \\
\hline $\mathrm{C} 17: 1$ & 0.73 & 0.71 & 0.03 & ns \\
\hline C18: 1 trans-11 (TVA) & 2.17 & 2.31 & 0.12 & ns \\
\hline $\mathrm{C} 18: 1$ cis -9 & 30.14 & 27.34 & 1.22 & ns \\
\hline C18: 1 trans -7 & 0.68 & 0.61 & 0.03 & ns \\
\hline $\mathrm{C} 20: 1$ & 0.23 & 0.24 & 0.02 & ns \\
\hline $\mathrm{C} 18: 2 \mathrm{n}-6(\mathrm{LA})$ & 2.69 & 2.84 & 0.20 & ns \\
\hline C18: 2 cis- 9, trans -11 (CLA) & 0.50 & 0.48 & 0.02 & ns \\
\hline $\mathrm{C} 18: 3 \mathrm{n}-3(\alpha \mathrm{LNA})$ & 0.56 & 0.49 & 0.03 & ns \\
\hline C18:3n-6 (GLA) & 0.20 & 0.19 & 0.01 & ns \\
\hline $\mathrm{C} 20: 3 n-3$ & 0.18 & 0.07 & 0.03 & $P \leq 0.01$ \\
\hline C20:4n-6 (AA) & 0.29 & 0.28 & 0.02 & ns \\
\hline $\mathrm{C} 20: 5 \mathrm{n}-3$ (EPA) & 0.03 & 0.02 & 0.00 & $P \leq 0.05$ \\
\hline C22: 5n-3 (DPA) & 0.20 & 0.14 & 0.03 & ns \\
\hline
\end{tabular}

ns: not significant, $P>0.5 ;{ }^{*} \mathrm{C} 16: 1$ iso (the cis/trans isomers of $\mathrm{C} 16: 1$ chromatographically unresolved); $\mathrm{SE}$ : standard error of the mean; LSM: least square mean; TVA: trans-vaccenic acid; GLA: gamma-linolenic acid; DPA: docosapentaenoic acid.

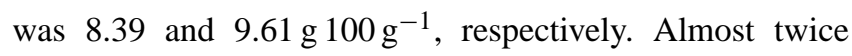
as large amount of SCFAs identified in the study of Polish mountain sheep and other dairy sheep breeds from the Mediterranean countries. This relates mainly to $\mathrm{C} 4: 0, \mathrm{C} 6: 0$ and C10 : 0 acids (Carta et al., 2002; Bonczar et al., 2009; de La Fuente et al., 2009). However, a similar amount of SCFAs to the present results was obtained by Gerchev and Mihay-

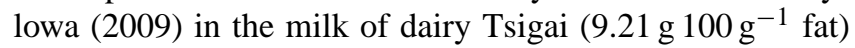
during the pasture season.

Among saturated fatty acids, myristic acid C14:0 and lauric acid $\mathrm{C} 12: 0$ are considered to be the most detrimental to human health. The higher amount of C14:0 as compared to the present results was found in the milk of Sicilio-Sarde

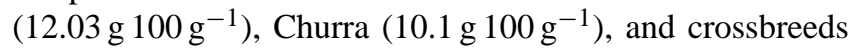

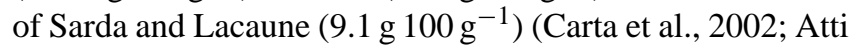
et al., 2006; de La Fuente et al., 2009).
There were no statistically significant differences in the amount of monounsaturated fatty acids (MUFAs) in the milk of the Wrzosówka breed and the Żelaźnieńska strain of Polish Lowland sheep (Table 5). The exception is C10:1 cis9 , of which there was more $(P \leq 0.01)$ in the milk fat of Wrzosówka ewes (Table 4). In the MUFAs group of fatty acids, both in the milk of Wrzosówka sheep and of Żelaźnieńska sheep, the highest proportion was noted with oleic acid (C18 : 1 cis-9) (82.8 and $81.4 \%)$, respectively. A lower amount of oleic acid was recorded by Atti et al. (2006) in

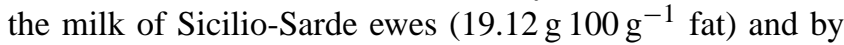
Bonczar et al. (2009) in the milk of Polish mountain sheep during pasture season. The amount of $\mathrm{C} 18: 1 \mathrm{cis}-9$ in the milk fat of Churra ewes, from Mediterranean countries, was

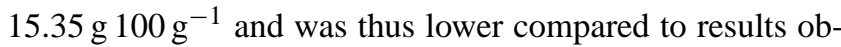
tained in the present study (de La Fuente et al., 2009). The amount of this fatty acid in the milk of Żelaźnieńska sheep 


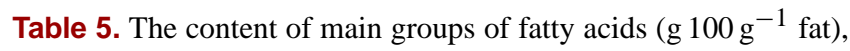
the content ratios of PUFAs, MUFAs to SFAs, the content ratio of PUFAs n-3 to PUFAs n-6, and the content of cholesterol and phospholipids ( $\mathrm{g} 100 \mathrm{~g}^{-1}$ fat)in milk of examined sheep breeds.

\begin{tabular}{lrrcc}
\hline $\begin{array}{l}\text { Fatty acids } \\
\text { group }\end{array}$ & $\begin{array}{r}\text { Wrzosówka } \\
n=30\end{array}$ & $\begin{array}{r}\text { Lowland sheep } \\
n=30\end{array}$ & SE & $\begin{array}{c}\text { Statistical } \\
\text { significance }\end{array}$ \\
\cline { 2 - 3 } & LSM & LSM & & \\
\hline SFAs & 55.61 & 56.6 & 2.00 & $\mathrm{~ns}$ \\
MUFAs & 36.37 & 33.56 & 1.41 & $\mathrm{~ns}$ \\
PUFAs & 4.70 & 4.57 & 0.27 & $\mathrm{~ns}$ \\
SMCFAs & 45.36 & 45.59 & 1.73 & $\mathrm{~ns}$ \\
LCFAs & 49.20 & 47.03 & 1.90 & $\mathrm{~ns}$ \\
C20-PUFAs & 0.75 & 0.56 & 0.05 & $\mathrm{~ns}$ \\
PUFAs/SFAs & 0.09 & 0.08 & 0.01 & $\mathrm{~ns}$ \\
MUFAs/SFAs & 0.66 & 0.62 & 0.02 & $\mathrm{~ns}$ \\
PUFAs n-3 & 1.03 & 0.78 & 0.03 & $P \leq 0.01$ \\
PUFAs n-6 & 3.17 & 3.31 & 0.18 & $\mathrm{~ns}$ \\
n-3/n-6 & 3.19 & 4.51 & 0.21 & $P \leq 0.01$ \\
Index T & 1.63 & 1.67 & 0.10 & $\mathrm{~ns}$ \\
Index A & 1.35 & 1.43 & 0.12 & $\mathrm{~ns}$ \\
TCh & 0.38 & 0.48 & 0.01 & $P \leq 0.05$ \\
Pl & 0.87 & 0.78 & 0.04 & $\mathrm{~ns}$ \\
\hline
\end{tabular}

ns: not significant, $P>0.5$; SE: standard error of the mean; LSM: least square mean; SFAs: saturated fatty acids; MUFAs: monounsaturated fatty acids; PUFAs: polyunsaturated fatty acids; SMCFAs: fatty acids with 17 carbon atoms; LCFAs: fatty acids with 18 carbon atoms; C20-PUFAs: polyunsaturated fatty acids with 20 carbon atoms; $n-3 / n-6$ : the concentration ratio of PUFAs n-3 to PUFAs n-6; Index T: thrombogenic index

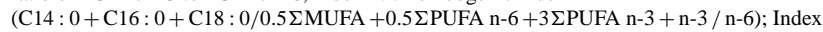
A: atherogenic index (C12:0+4xC14:0+C16:0/ $\Sigma$ MUFA + $\Sigma$ PUFA n-6 and n-3) (Morán et al., 2013); TCh: total cholesterol; Pl: phospholipids.

was similar to Kachi, a non-dairy sheep breed from Pakistan

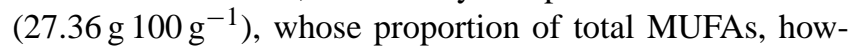
ever, was much higher (90\%) compared to the studied breeds (Talpur et al., 2009).

The lower amount of MUFAs, compared to the present study reported in milk fat of Polish mountain sheep and Friesian Sheep (Patkowska-Sokoła et al., 2005). The amount of MUFAs was also lower in the milk of Sicilio-Sarde

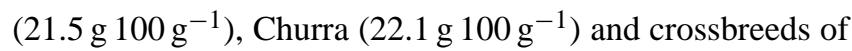

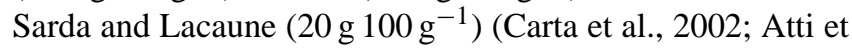
al., 2006; de La Fuente et al., 2009).

Although polyunsaturated fatty acids (PUFAs) only occur in small amounts in sheep milk, they can perform extremely important functions in living organisms. There were no statistically significant differences in the amount of acids with 18 carbon atoms in the chain in the milk fat of both examined breeds.

The share of PUFAs in both studied sheep breeds accounted for about $5 \%$ of all fatty acids assessed. Between these breeds, there were no statistically significant differences in this group of fatty acids or in the ratio of PUFAs / SFAs (Table 2). However, in Wrzosówka sheep, milk fat showed higher amounts $(P \leq 0.01)$ of PUFAs n-3 and consequently improved the ratio $(P \leq 0.01)$ of $n-6 / n-3$ in this breed (Table 5). The milk of the more primitive breed (Wrzosówka) was favorable in terms of the health benefits of fatty acids; this is confirmed by the values of atherogenic and thrombogenic indexes, although the differences between studied breeds were not confirmed statistically (Table 5).

A higher amount of PUFAs, including n-3 linolenic acid ( $\alpha$ LNA) was reported by Patkowska-Sokoła et al. (2005) in the milk fat of Polish mountain sheep and Friesian sheep during grazing compared to both studied non-dairy sheep breeds. The milk obtained from a dairy breed from northern Sardinia contained higher amounts of PUFAs than the milk of Wrzosówka and Żelaźnieńska sheep (19 and 20\%, respectively; Nudda et al., 2005). In the milk of Churra sheep, the amount of this group of acids was higher by $40 \%$ compared to the studied breeds. In addition, their percentage share in the total fatty acids of milk was higher and amounted to $9 \%$. However, Atti et al. (2006), analyzing the fatty acids profile of the milk of dairy Sicilio-Sarde ewes fed hay, silage and grain concentrate, found a much lower amount of PUFA

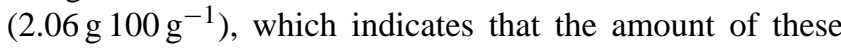
acids may be more closely related to nutrition, which indicates that the amount of these acids rather than their effect may be more relevant with regard to nutrition. Allowing sheep to graze more contributes to an increase in PUFAs, especially $\mathrm{C} 18: 3$, in the milk of grazing ewes. The amount of PUFAs was also lower in the milk of the non-dairy

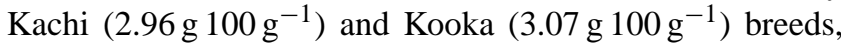
compared to both studied breeds (Talpur et al., 2009).

The amount of conjugated linoleic acid isomers, especially C18 : 2 cis-9, trans-11, in the lipid fraction of the milk of $\mathrm{Wr}$ zosówka sheep and the Żelaźnieńska strain of Polish Lowland sheep was similar (Table 4).

According to many authors, feeding is the key factor that influences the amount of $\mathrm{C} 18: 2$ cis-9, trans 11 in milk. The highest differences were reported between summer feeding (with a large share of green forages) and winter feeding (Nudda et al., 2005; Collomb et al., 2006; Scollan et al., 2014). Pasture feeding is a rich source of linolenic acid and provides a precursor (C18:1 trans 11$)$ for endogenous synthesis of CLA. A higher amount of cis-9, trans11 CLA, compared to the results obtained here, was found by PatkowskaSokoła et al. (2005), in the milk of Polish mountain sheep and Friesian sheep during grazing; the amount was 0.9 and $0.71 \%$, respectively, of the total fatty acids. In the milk of Tsigai and Sicilio-Sarde, kept on pasture, the amount of CLA was also higher than in the present study (Atti et al., 2006; Gerchev and Mihaylova, 2009). A similar amount of this isomer to the results obtained was reported by Tsiplakau et al. (2006) in milk of typical milk breeds such as Awassi $(0.46 \%)$, Lacaune $(0.44 \%)$, Friesian sheep $(0.35 \%)$ and Chios $(0.46 \%)$ that were kept under the same nutritional conditions as the breeds studied.

In the milk of Wrzosówka sheep, the amount $(P \leq 0.05)$ of cholesterol was lower than in the Żelaźnieńska strain of Polish Lowland sheep (Table 5). Goudjil et al. (2003), analyzing cholesterol content and other sterol fractions of the milk of Churra, Awassi, crossbreeds of Assaf and Castel- 
lana, Manchega and Assaf from different regions of Spain, reported a slightly lower amount of cholesterol, within the

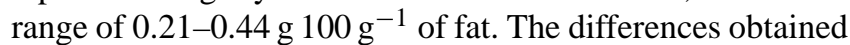
were the result of the season at milk collection rather than of the breed. Other studies have shown that the cholesterol level in milk can be affected by the stage of lactation (Boersma et al., 1991). In the present study nutritional conditions and the stage of lactation were unified for both breeds. It has to be emphasized that attaching too much importance to the level of cholesterol in milk may lead to a lack of appreciation of its other functional components (Maijala, 2000).

The level of phospholipids in milk of both studied breeds was similar, and the differences were not confirmed statistically (Table 5). The phospholipid level increases as the diameter of fat globules decreases. The smaller diameter of fat globules in the sheep milk explains its fat content, which is almost 3 times higher than that of cow milk ( 0.30

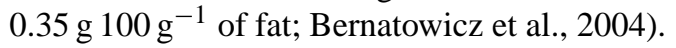

In the present study, the maintenance and physiological state of the studied sheep breeds was uniform; the lack of differences in the amount of phospholipids in milk fat between the studied breeds may thus indicate that breed did not influence the level of these components.

\section{Conclusions}

The milk of the non-dairy sheep breeds examined, maintained under the same nutritional conditions, did not differ in terms of the amount of basic components.

The higher concentration of PUFAs in the milk lipid fraction was found in the more primitive sheep breed $\mathrm{Wr}$ zosówka. Our research suggests that native, non-dairy sheep breeds can provide high-quality milk, rich in PUFAs, which is mostly consumed by suckling lambs. Thereby, this milk can positively affect the carcass quality of lambs slaughtered at a low weight.

Edited by: S. Maak

Reviewed by: two anonymous referees

\section{References}

AOAC (Association of Official Analytical Chemists): Food Composition Additives, Natural Contaminants, 15th Edn., Arlington, TX, USA, 963 pp., 1990.

Atti, N., Rouissi, H., and Othmane, M. H.: Milk production, milk fatty acid composition and conjugated linoleic acid (CLA) content in dairy ewes raised on feedlot or grazing pasture, Livest. Sci., 104, 121-127, 2006.

Bernatowicz, E., Reklewska, B., Zdziarski, K., and Karaszewska, A.: Milk content of functional components as affected by the health status of mammary gland, Zeszyty Naukowe Przegladu Hodowlanego., 72, 185-193, 2004.

Boersma, E. R., Offringa, P. J., Muskiet, F. A. J., and Chase, W. M.: Vitamin E, lipid fractions, and fatty acid composition of colostrums, transitional milk and mature milk: an international study, Am. J. Clin. Nutr., 53, 1197-1204, 1991.

Bonczar, G., Reguła-Sardat, A., Pustkowicz, H., and Żebrowska, A.: Effect of mixing of ewe's and cow's milk on bundz cheese properties, Food Science Technology Quality, 5, 96-106, 2009.

Carta, A., Piredda, G., Addis, M., Cabiddu, A., Fiori, M., Leroux, C., and Barillet, F.: Fatty acid composition of sheep milk from a backcross Sarda x Lacaune resource population: preliminary QTL detection for CLA content, Options Mediterranéennes, 55, 107-113, 2002.

Collomb, M., Schmid, A., Sieber, R., Wechsler, D., and Ryhänen, E. L.: Conjugated linoleic acids in milk fat. Variation and physiological effects, Int. Dairy J., 16, 1347-1361, 2006.

de La Fuente, L. F., Barbosa, E., Carriedo, J. A., Gonzalo, C., Arenas, R., and Fresno, J. M.: Factors influencing variation of fatty acid content in ovine milk, J. Dairy Sci., 92, 3791-3799, 2009.

Gerchev, G. and Mihaylova, G.: Variation in fatty acid composition of milk from Tsigai sheep in the region of central Balkan mountains, Biotech. Animal Husb., 25, 945-952, 2009.

Goudjil, H., Torrado, S., Fontecha, H., Martínez-Castro, I., Fraga, M. J., and Juárez, M.: Composition of cholesterol and its precursors in ovine milk, Le Lait, 83, 153-160, 2003.

Haenlein, G. F. W.: The nutritional value of sheep milk, Int. J. Animal Sci., 16, 253-268, 2001.

Holme, D. J. and Peck, H.: Analytical Biochemistry, Longman Scientific and Technical, New York, USA, 12, p. 422, 1994.

Huth, P. J. and Park, K. M.: Influence of dairy product and milk fat consumption on cardiovascular disease risk: a review of the evidence, Adv. Nutr., 3, 266-285, 2012.

Maijala, K.: Cow milk and human development and well-being, Livest. Prod. Sci., 65, 1-18, 2000.

Molik, E., Murawski, M., Bonczar, G., and Wierzchoś, E.: Effect of genotype on yield and chemical composition of sheep milk, Anim. Sci. Pap. Rep., 26, 211-218, 2008.

Morán, L., Giráldez, F. J., Panseri, S., Aldai, N., Jordán, M. J., Chiesa, L. M., and Andrés, S.: Effect of dietary carnosic acid on the fatty acid profile and flavour stability of meat of fattening lambs, Food Chem., 138, 2407-2414, 2013.

Nudda, A., Mcguire, M. A., Battacone, G., and Pulina, G.: Seasonal variation in conjugated linoleic acid and vaccenic acid in milk fat of sheep and its transfer to cheese and ricotta, J. Dairy Sci., 88, 1311-1319, 2005.

Osikowski, M., Porębska, W., and Korman, K.: Sheep nutrition standards, in: Traditional feeding standards for cattle and sheep, edited by: Ryś, R., Wyd. XII. IZ Cracow, Poland, 27-59, 1998.

Park, Y. W., Juárez, M., Ramos, M., and Haenlein, G. F. W.: Physico-chemical characteristics of goat and sheep milk, Small Rum. Res., 68, 88-113, 2007.

Parodi, P. W.: Anti-cancer agents in milk fat, Aust. J. Dairy Tech., 58, 114-118, 2003.

Parodi, P. W.: Milk fat in human nutrition, Aust. J. Dairy Tech., 59, 3-59, 2004.

Patkowska-Sokoła, B., Ramadani, S., and Bodkowski, R.: Skład chemiczny mleka polskiej owcy górskiej i owcy fryzyjskiej z okresu żywienia pastwiskowego, Rocz. Nauk. Zoot., 21, 73-75, 2005.

Puppel, K.: The influence of fish oil and linseed supplementation on the fat and the protein fraction content of cow's milk, $\mathrm{PhD}$ thesis, Warsaw University of Life Sciences, Warsaw, Poland, 2011. 
Puppel, K., Kuczyńska, B., Nałęcz-Tarwacka, T., Gołębiewski, M., Sakowski, T., Kapusta, A., Budziński, A., Balcerak , M.: Effect of supplementation of cows diet with linseed and fish oil and different variants of B-lactoglobulin on fatty acids composition and antioxidant capacity of milk, J. Sci. Food Agric., doi:10.1002/jsfa.7341, online first, 2015.

Radzik-Rant, A., Rozbicka-Wieczorek, A., Czauderna, M., Rant, W., and Kuczyńska, B.: The chemical composition and fatty acid profile in milk of Polish Mountain Sheep and Polish Merino, Anim. Sci., 49, 163-172, 2011.

Radzik-Rant, A., Rant, W., Rozbicka-Wieczorek, A., and Kuźnicka, E.: The fatty acid composition of longissimus lumborum muscle of suckling and early-weaned dual-purpose wool/meat lambs, Arch. Tierzucht, 55, 285-293, 2012.

Rozbicka-Wieczorek, A., Radzik-Rant, A., Rant, W., and Czauderna, M.: The content of Conjugated Linoleic Acid (CLA) Isomer Groups in Milk of two Polish Sheep Breeds determined by Silver ion Liquid Chromatography (Ag+HPLC), Fol. Boil., 61, 107-111, 2013.
Scerra, M., Caparra, C., Foti, F., Galofaro, V., Sinatra, M. C., and Scerra, V.: Influence of ewe feeding systems on fatty acid composition of suckling lambs, Meat Sci., 76, 390-394, 2007.

Scollan, N. D., Dannenberger, D., Nuemberg, K., Richardson, I., Mackintosh, S., Hocquette, J. F., and Moloney, A. P.: Enhancing the nutritional and health value of beef lipids and their relationship with meat quality, Meat Sci., 97, 384-394, 2014.

SPSS: User's Guide 12.0, SPSS Inc., Chicago, IL, USA, 2003.

Talpur, F. N, Bhanger, M. I., and Memon, N. N.: Milk fatty acid composition of indigenous goat and ewe breeds from Sindh, Pakistan J. Food Comp. Anal., 2, 59-64, 2009.

Tsiplakou, E., Mountzouris, K. C., and Zerves, G.: The effect of breed, stage of lactation and parity on sheep milk fat CLA content under the same feeding practices, Livest. Sci., 105, 162-167, 2006. 